\title{
STANDART KOMPETENSI AMIL DALAM UPAYA MENGELOLA GERAKAN KOIN NU PEDULI UNTUK KESEJAHTERAAN MASYARAKAT MISKIN
}

\author{
Oleh \\ Mukhamad Zakariya \\ Institut Agama Islam Pangeran Diponegoro Nganjuk \\ mukhamadzakaria@iaipd-nganjuk.ac.id
}

\begin{abstract}
The NU Peduli coin movement was a social movement carried out by Nahdiliyin residents by collecting coins from the home of Nahdlatul Ulama residents. This program is a form of follow-up from the cadre activator program of Nahdlatul Ulama (PKPNU) which has recently been intensified. The program, which has been running for more than 2 years, was initiated by the Nahdlatul Ulama Executive Board which was then continued at the Provincial, City / District, District to Village levels. Capitalized by hundreds of PKPNU alumni of this movement received a positive response from Nahdliyyin circles. The small coins that have been collected on the distributed cans will be taken every month and put together, then managed to be divided and distributed to mustahik. However, in the course of this positive movement was felt to be less than optimal because of several factors that were far from the standard of competence such as a less optimal division of tasks, delays in the distribution of cans, weak financial management of officers.
\end{abstract}

Keywords: Competency Standards, NU Care Coins, Community Welfare

\begin{abstract}
Abstrak
Gerakan koin NU Peduli merupakan gerakan sosial yang dilakukan oleh warga Nahdiliyin dengan cara mengumpulkan uang receh (koin) dari rumah rumah warga Nahdlatul Ulama. Program ini sebagai
\end{abstract}


bentuk tindaklanjut dari program kader penggerak Nahdlatul Ulama (PKPNU) yang belakangan ini digencarkan. Program yang sudah berjalan lebih dari 2 tahun tersebut digagas oleh Pengurus Besar Nahdlatul Ulama yang kemudian diteruskan pada tingkat Provinsi, Kota/Kabupaten, Kecamatan hingga Desa. Bermodal ratusan alumni PKPNU gerakan ini mendapat respon positif dari kalangan Nahdliyyin. Uang receh yang berhasil terkumpul pada kaleng-kaleng yang sudah disebar akan diambil setiap bulan sekali dan dijadikan satu, kemudian dikelola untuk dibagi serta disalurkan pada mustahik. Namun, dalam perjalanannya gerakan positif ini dirasa kurang maksimal karena beberapa faktor yang jauh dari standart kompetensi misalnya pembagian tugas yang kurang maksimal, terlambatnya distribusi kaleng, lemahnya manajemen keuangan petugas.

Kata Kunci: Standart Kompetensi, Koin NU Peduli, Kesejahteraan Masyarakat

\section{Pendahuluan}

Gerakan koin NU Peduli adalah Gerakan Nahdiliyin untuk mengumpulkan uang receh (koin) dari rumah rumah Nahdliyin, yang manfaatnya untuk memberikan solusi bagi nahdliyin dalam berbagai aspek kehidupan dan mewujudkan kemandirian jam'iah. ${ }^{134}$

Harta yang didapat dengan baik dimanfaatkan disalurkan dengan baik, sesuai dengan tuntunana agama Islam meruapakan harta yang berkah itulah yang akan membawa kesejahteraan bagi pemiliknya. Bersedekah merupakan ajaran yang dilandasi bertumbuh kembangnya sebuah kekuatan sosial ekonomi umat Islam. Konsepsi pengentasan kemiskinan umat, melalui pengamalan sedekah yang diajarkan dalam islam merupakan salah satu alternatif yang dapt ditempuh dalam mengatasi masalah sosial yang dimaksud. Potensi gerakan koin NU Peduli yang cukup signifikasi tersebut perlu digali secara optimal agar dapat digunakan untuk ikut menggerakkan

${ }^{134}$ Asnani Zakat Produktif Dalam Perfektif Hukum Islam Yogyakarta: Putaka Pelajar, 2013, 1. 
perekonomian umat, di samping potensi-potensi yang lain, sehingga taraf hidup umat menjadi terangkat. Namun yang menjadi masalah selama ini antara lain penggelolaan gerakan koin NU Peduli yang belum dilakukan secara professional sehingga pengumpulan dan penyaluran gerakan koin NU peduli menjadi kurang teratur. Disamping masih rendahnya pemahaman masyarakat permasalahan gerakan koin NU Peduli.

Adapun pendayagunaan dalam gerakan koin NU Peduli erat kaitannya dengan bagaimana cara pengelolaan serta pendistribusian. Kondisi itu dikarenakan jika penggelolaan secara optimal dan pendistribusian secara tepat sasaran dan tepat guna, maka pengelolaan serta pendistribusian akan lebih optimal. Adapun jenis-jenis kegiatan pendayagunaan dana gerakan koin NU Peduli, yaitu: berbasis sosial dan berbasis pengembangan ekonomi. Adapun pendayagunaan gerakan koin NU Peduli berbasis sosial adalah dilakukan dalam bentuk pemberian dana langsung berupa gerobak ataupun santunan sebagai bentuk pemenuhan usaha dan pemenuhan kebutuhan mustahik. Ini disebut juga program karitas (santunan). Program ini merupakan bentuk yang paling sederhana dari penyaluran dana gerakan koin NU Peduli. tujuan utama bentuk penyaluran ini adalah a) Untuk menjaga keperluan usaha dan keperluan pokok mustahik. b) Menjaga martabat dan kehormatan mustahik untuk memperoleh atau meningkatkan pendapatan. c) Mencegah terjadinya eksploitasi terhadap mustahik untuk kepentingan yang menyimpang. ${ }^{135}$

Sedangkan pendayagunaan gerakan koin NU Peduli berbasis pengembangan ekonomi adalah dilakukan dalam bentuk pemberian gerobak usaha kepada mustahik secara langsung maupun tidak langsung, yang pengelolaannya bisa melibatkan maupun tidak melibatkan mustahik sasaran. Penyaluran dana gerakan koin NU Peduli ini diarahkan pasa usaha ekonomi yang produktif, yang

${ }^{135}$ Asnani Zakat Produktif Dalam Perfektif Hukum Islam

Yogyakarta: Putaka Pelajar, 2013,2

Volume 6 No.1 Januari 2019 
diharapkan hasilnya dapat mengangkat taraf kesejahteraan masyarakat dalam pengentasan kemiskinan. ${ }^{136}$

Untuk menentukan arah dan tujuan dalam pengelolaan gerakan koin NU Peduli agar langkahnya dapat lebig produktif dan mempunyai nilai yang lebih dari saat sekarang, sehingga diperlukan metode-metode yang dapat dipergunakan sebagai alat untuk membantu hal tersebut hal disebut dengan perencanaan stategis agar dapat mengelola gerakan koin NU Peduli dengan baik. Perencanaan strategis merupakan sebuah alat manajemen, alat itu hanya digunakan untuk satu maksud saja menolong organisasi melakukannya tugasnya dengan lebih baik. Dalam pendistribusian gerakan koin NU Peduli muzakki menyalurkan gerkan koin NU Peduli melalui ranting ataupun dari MWCNU setempat. Sedangkan LAZISNU hanya menerima sebagian sisa penyaluran untuk acara sosialisasi gerakan koin NU Peduli semua daerah.

Hingga saat ini pengelolaan gerakan koin NU Peduli dalam pendayagunaan di Indonesia, khususnya di kabupaten Nganjuk, masih jauh dari optimal, apabila kita membandingkan antara besarnya dana gerakan koin NU Peduli yang berhasil dikumpulkan oleh para ranting ataupun MWCNU. Beragam faktor dapat dikatakan sebagai penyebabnya, antara lain, minimnya kesadaran untuk bersedekah dan rendahnya kepercayaan terhadap ranting ataupun MWCNU. Selain itu, Lembaga Amil Zakat yang diharapkan menjadi tulang pungung pengelolaan gerakan koin NU Peduli sebagaimana dititahkan oleh syariat belum optimal penggelolan gerakan koin NU Peduli, sejauh mana kemiskinana itu bisa terbantu dengan adanya gerakan koin NU Peduli. ${ }^{137}$ Untuk itu peneliti tertarik untuk melakukan penelitian mengenai kepercayaan muzaki terhadap strategi pengelolaan ZIS di LAZISNU Cabang Nganjuk.

${ }^{136}$ Isma'il Nawawi, Zakat Dalam Perspektif Fiqh, Sosial Dan Ekonomi, Cet Ke Isurabaya:Putra Media Nusantara, 2010), HIm.91 ${ }^{137}$ Ibid, hal 92 


\section{Metode Penelitian}

Peneliti menggunakan jenis penelitian kualitatif yakni penelitian yang menekankan pada studi kasus atau hal yang terpenting dari sifat suatu barang/jasa. Penelitian kualitatif dapat didesain untuk memberikan memberikan sumbangannya terhadap teori, praktis, kebijakan, masalah-masalah social dan tindakan. Suatu penelitian kualitatif dieksplorasi dan diperdalam dari suatu fenomena sosial atau suatu lingkungan social yang terdiri atas pelaku, kejadian, tempat dan waktu. Menjelaskan pengertian penelitian sebagai suatu kegiatan yang dilakukan secara sistematik untuk mengumpulkan, mengolah, dan menyimpulkan data dengan menggunakan metode dan teknik tertentu dalam rangka mencari jawaban atas permasalahan yang dihadapi.

Metode penelitian kualitatif adalah metode penelitian yang digunakan untuk meneliti pada kondisi objek yang alamiah, (sebagai lawannya adalah eksperimen) dimana peneliti adalah sebagai instrumen kunci, teknik pengumpulan data yang dilakukan secara triangulasi (gabungan), analisis data bersifat induktif, dan hasil penelitian.Kualitatif lebih menekankan makna dari pada genealisasi. Mendefiniskan bahwa penelitian kualitatif adalah tradisi tertentu dalam ilmu pengetahuan sosial yang secara fundamental bergantung pada pengamatan pada manusia dalam kawasan sendiri dan berhubungan dengan orang-orang tersebut dalam bahasannya dan dalam peristilahannya. ${ }^{138}$

Adapun jenis pendekatan penelitian ini adalah deskriptif. Penelitian deskriptif yaitu penelitian yang berusaha untuk memutuskan pemecahan masalah yang ada sekarang berdasarkan data-data. Jenis penelitian deskriptif kualitatif yang digunakan pada penelitian ini dimaksudkan untuk memperoleh informasi mengenai peran manager dalam meningkatkan kesejahteraan masyarakat yang terdapat di LAZISNU Cabang Nganjuk.

2014,1

${ }^{138}$ Sugiyono, Memahami Penelitian Kualitatif, Bandung: alfabeta, 


\section{Hasil dan Pembahasan}

Manajemen dalam kamus bahasa Indonesia, diartikan proses penggunaan sumber daya secara efektif untuk mencapai sasaran. ${ }^{139}$ Dalam istilah manajemen terdapat tiga pandangan yang berbeda, pertama: mengartikan administrasi lebih luas dari pada manajemen (manajemen merupakan inti dari administrasi), kedua: melihat manajemen lebih luas dari administrasi dan ketiga: pandangan yang beranggapan bahwa manajemen identik dengan administrasi. ${ }^{140}$ Makna manajemen sering diartikan sebagai ilmu, kiat dan profesional. Manajemen diartikan sebagai ilmu karena merupakan suatu bidang ilmu pengetahuan yang secara sistematik berusaha memahami mengapa dan bagaimana orang bekerja sama. Manajemen diartikan sebagai kiat karena manajemen mencapai sasaran melalui cara-cara dengan mengatur orang lain menjalankan tugasnya.

Sedangkan manajemen diartikan sebagai profesi karena manajemen dilandasi oleh keahlian khusus untuk mencapai suatu prestasi manajer, dan para professional dituntut oleh suatu kode etik. $^{141}$ Intik memahami istilah manajemen, pendekatan yang digunakan adalah berdasarkan pengalaman manajer. Manajemen sebagai suatu sistem yang komponennya menampilkan sesuatu untuk memenuhi kebutuhan. Dengan demikian maka manajemen merupakan suatu proses untuk mencapai tujuan organisasi secara efektif dan efisien. Pencapaian tujuan-tujuan organisasi dilaksanakan dengan penggelolaan fungsi-fungsi perencanaa (planning), pengorganisasian (organizing), penyusunan personalia atau kepegawaian (staffing), pengarahan dan kepemimpinan (leading), dan pengawasan (controlling). ${ }^{142}$

${ }^{139}$ Lukman Ali, dkk, Kamus Besar Indonesia Cet II Jakarta: Balai Pustaka, 2010, 623

${ }^{140}$ E. Mulyasa, Manajemen Berbasis Sekolah, Cet I Bandung: Pt. Remaja Rasindo, 2010,19

${ }^{141}$ Nanang Fattah, Landasan Manajemen Pendidikan, Set III Bandung: Alumni, 2010, I

${ }^{142}$ Winardi, Asaz-Asaz Manajemen, Cet III Bandung: Alumni, 2010 , .4 
Aktivitas manajemen mencakup spectrum yang sangat luas, sebab dimulai dari bagaimana mementukan arah organisasi di masa depan, sampai mengawasi kegiatan untuk mencapai tujuan. Maka dalam rangka mencapai tujuan organisasi secara efektf dan efisien manajemen harus difungsikan sepenuhnya pada setiap organisassi, adapun fungsi-fungsi manajemen dapat dijelaskan sebagai berikut:

1. Perencanaan

Perencanaan merupakan salah satu hal yang penting yang perlu di buat untuk setiap usaha dalam rangka mencapai suatu tujuan.karena seringkali pelaksanaan suatu kegiatan akan mengalami sesuatu kesulitan dalam mencapai tujuan tanpa adanya perencanaanya. ${ }^{143}$ Kesulitan tersebut dapat berupa penyimpanan arah dari pada tujuan, atau ada pemborosan modal yang mengakibatkan gagalnya semua kegiatan dalam mencapai suatu tujuan. Dalam perencanaan terdapat sumber-sumber perencanaan sebagai berikut

a. Kebijakan pucuk pimpinan (policy of management), bahwa perencanaan itu sering kali berasal dari badan-badan ataupu orang-orang yang berhak dan mempunyai wewenang untuk membuat berbagai kebijakan, sebab merekalah para pemegang kebijakan.

b. Hasil pengawasan, yaitu suatu perencanaan akan dibuat aras dasar fakta-fakta maupun data-data dari hasil pengawasan suatu kegiatan kerja, sehingga dengan demikian dibuatlah suatu perencanaan perbaikan maupun peyesuaian ataupun perombakan secara menyeluruh dari pada rencana yang telah dilaksanakan.

c. Kebutuhan masa depam, yaitu suatu perencanaan sengaja dibuat untuk mempersiapkan masa depan yang baik ataupun untuk mencegah hambatan-hambtan dari rintangan guna mengatasi persoalan-persoalan yang akan timbul.

d. Penemuan-penemuan baru, yaitu suatu perencanaan dibuat berdasarkan studi factual ataupun yang terus menerus maka akan

${ }^{143}$ Syafaruddin, Manajemen Lembaga Pendidikan Islam, Jakarta: Ciputat Press, 2012,.61. 
menemukan ide-ide ataupun pendapat baru, ataupun prakarsa baru untuk suatu kegiatan kerja.

e. Prakarsa dari luar, yaitu suatu rencana yang dibuat akibat dari saran-saran maupun kritik-kritik dari orang-orang di luar organisasi ataupun dari masyarakat luas. ${ }^{144}$

Dengan demikian dapat disimpulkan bahwa sumber perencanaan adalah hasil yang dibuat atas dasar fakta-fakta maupun data-data pada hasil pengawasan suatu kegiatan kerja, yang sengaja dibuat untuk mempersiapkan masa depan yang baik ataupun untuk mencegah hambatan-hambatan dan rintangan-rintangan guna mengatasi persoalan-persoalan yang akan timbul.

2. Pengorganisasian

Menurut Terry sebagaimana ditulis oleh Ulbert silalahi adalah pembagian pekerjaan yang direncanakan untuk diselesaikan oleh anggota kelompok pekerjaan, penentuan hubungan-hubungan pekerjaan diantara mereka dan pemberian lingkungan pekerjaan yang sepatunya. ${ }^{145}$ Pengorganisasian merupakan salah satu fungsi manajemen yang perlu mendapat perhatian dari kepala sekolah. Fungsi ini perlu dilakukan untuk mewujudkan struktur organisasi sekolah, uraian tugas tiap bidang, wewnang dan tanggungjawab menjadi lebih jelas, dan penetuan sumber daya manusia dan materil yang diperhatikan. Menurut Robbins, bahwa kegiatan yang dilakukan dalam pengorganisasian dapat mencakup 1. Menetapkan tugas yang harus dilakukan, 2. Siapa yang mengerjakkan., 3. Bagaimana tugas itu dikelompokkan, 4. Siapa yang melapor, 5. Dimana keputusan itu harus diambil.

Dengan demikian, pengorganisasian merupakan fungsi administrasi dapat disimpulkan sebagai kegiatan menyusun struktur dan membentuk hubungan-hubungan agar diperoleh kesesuaian dalam usaha mencapai tujuan bersama. Pengorganisasian yang baik memungkinkan semua bagian dapat bekerja dalam kelarasan, dan menjadi bagian dalam keseluruhan yang tak terpisahkan. Unsur

\footnotetext{
${ }^{144}$ Ibid,.62

${ }^{145}$ Ibid,.65
} 
pemersatu yang pertama adalah tujuan yang hendak dicapai, kedua adalah yang mempersatukan kewenangan,, yaitu hak dan kekuasaaan untuk melakukan sesuatu atas dasar kedudukan yang ditempati seseorang, ketiga adalah pengetahuan yang dianggap sebagai pemersatu karena uia adalah dasar bagi pengertian dan kesesuaian paham diantara pra anggota organisasi dan menjadi pedoman bagi sikap dan perbuatan mereka. ${ }^{146}$

Mengorganisasikan adalah proses mengatur, mengalokasikan dan mendistribusikan pekerjaan, wewenang dan sumber daya diantara anggota organisasi untuk mencapai tujuan organisasi. stoner, menyatakan bahwa mengorganisasikan adalah proses mempekerjaakan dua orang atau lebih untuk bekerja sama dalam cara terstruktur guna mencapai sasaran.

Mengorganisasikan berarti: 1. Menentukan sumber daya dan kegiatan yang dibutuhkan untuk mencapai tujuan organisasi, 2. Meranvang dan mengembangkan kelompok kerja yang berisi orang yang mapu organisasi pada tujuan, 3. menugaskan seseorang atau kelompok orang dalam suatu tanggung jawab tugas dan fungsi tertentu, 4. Mendelegasikan wewenang kepada individu yang berhubungan dengan keleluasaan tuga. Dengan rincian tersebut, manajer membuat suatu struktur formal yang dapat dengan mudah dipahami orang dan menggambarkan suatu porsi dan fungsi seseorang di dalam pekerjaannya.

Mengorganisasikan sangat penting dalam manajemen karena membuat posisi orang jela dalam struktur dan pekerjaannya dan melalui pemilihan, pengalokasian dan pendistribusian kera yang rofesional, organisasi dapat mencapai tujuan secara efektif dan efisien. Dalam mengorganisasikan seorang manajer jelas memerlukan kemampuan memahami sifat pekerjaan (job specification) dan kualifikasi orang yang harus mengisi jabatan. Dengan demikian kemampuan menyusun personalia yang terdapat pada suatu lembaga pendidikan adalah meliputi kepala, wakil kepala, bendahara, sekretaris

${ }^{146}$ Ibid,.66 
dan bagian-bagian lain yang sesuai dengan tugas dan tanggung jawab masing-masing.

Menurut Siagian sebagaimana yang dikutip oleh marno, ia menyebutkan bahwa ada lima belas prinsip-prinsip organisasi, yakni: 1. Kejelasan tujuan yang ingin dicapai, 2. Pemahaman tujuan oleh para anggota organisasi, 3. Penerimaan tujuan oleh para anggota organisasi, 4. Adanya kesatuan arah, 5. Kesatuan perintah, 6. Adanya fungsionalisasi, 7. Delenisasi berbagai tugas, 8. Keseimbangan antara wewenang dan tanggung jawab, 9. Adanya pembagian tugas, 10. Kesederhanaan struktur, 11. Adanya pola dasar organisasi yang relatif permanen, 12. Adanya pola pendelegasian wewenang, 13. Rentang pengawasan, 14. Jaminan pekerjaan, 15. Keseimbangan anrata jasa dan imbalan. Kesimpulan bahwa organisasi merupakan sarana bagi kerja sama yang efektif dan efisien. Hubungan keorganisaian akan berlangsung dengan baik jika didasrkan atas prinsip scalar, prinsip kemutlakan prinsip kesatuan perintah, dan juga prinsip tingkatan otoritas.

\section{Penggerakan}

Penggerakan atau actuating merupakan hubungan erat antara aspek-aspek individual yang ditimblkan dari adanya pengaturan terhadap bawahan untuk dapat dimengerti dan pembagian kerja yang efektif dan efisien untuk mencapai tujuan perusahaan yang nyata.

Pengertian diatas merupakan kejelasan bahwa penggerakan adalah kegiatan untuk mengarahkan orang lain agar suka dan dapat bekerja dalam upaya mencaapi tujuan. Pada pengertian di atas terdapat penekanan tentang keharusan cara yang tepat digunakan untuk menggerakkan, yaitu dengan cara memotivasi atau memberi motifmotif bekerja kepada bawahanya agar mau dan senang melakukan segala aktivitas dalam rangka mencapai tujuan secara efektif dan efisien. Lebih lanjut siagian mengemukakan bahwa alasan pentingnya pelaksanaan fungsi penggerakan dengan cara memotivasi bawahan dalam bekerja adalah: a) Motivating secara implisit berarti bahwa pemimpin organisasi berada di tengah-tengah bawahanya dan dengan dapat memberikan bimbinga, intruksi, nasehat dan koreksi jika diperlukan; b) Secara implisit pula, dalam motivasi telah mencakup 
adanya upaya untuk mengsingkronisasikan tujuan organisasi dengan tujuan-tujuan pribadi dari para anggota organisasi; c) Secara eksplisit dalam pengertian ini terlihat bahwa para pelaksanan operasional organisasi dalam memberikan jasa-jasanya memerlukan beberapa perangsang atau insentif. Motivasi sebagai bagian penting dari fungsi penggerkaan, Karena motivasi merupakan keinginan yang terdapat pada seseorang merangsang untuk melakukan tindakan-tindakan.

4. Pengawasan

Secara etimologis "controlling" lazimnya diterjemahkan dengan "pengendalian". Geprge R. Terry merumuskan pengawasan (controlling) sebagai suatu usaha untuk meneliti kegiatan-kegiatan yang telah dilaksanakan. Pengawasan berorientasi pada objek yang dituju dan merupakan alat untuk menyuruh ornag-orang bekerja menuju sasaran yang ingin dicapai. ${ }^{147}$

Pengawasan atau pengendalian adalah pengukuran dan perbaikan terhadap pelaksanaan kerja bawahan agar rencana-rencana yang telah dibuat untuk mencapai tujuan organisasi dapat terselenggara dengan baik. Uraian tersebut menggambarkan bahwa pengawasan dapat dirumuskan sebagai proses penentuan apa yang akan dicapai, yaitu standar apa yang sedang dilakukan, menilai pelaksaan, dan bilamana perlu melakukan perbaikan-perbaikan sehingga pelaksanaan sesuai dengan rencana yang telah ditetapkan.

Bertolak dari uraian di atas, menurut dari Triyo, ada beberapa unsur yang perlu diketahui dalam proses pengawasan ini diantara lain:

a. Adanya proses dalam menetapkan pekerjaan yang telah dan akan dikerjakan

b. Merupakan alat untuk menyeruh orang bekerja menuju sasaransasaran yang ingin dicapai.

c. Memonitor, menilai dan mengoreksi pelaksaan pekerjaan.

d. Mengukur tingkat efektivitas kerja ${ }^{148}$

${ }^{147}$ Syafaruddin, Manajemen Lembaga Pendidikan Islam, Jakarta:

Ciputat Press, 2012, .74

${ }^{148}$ Syafaruddin, Manajemen Lembaga Pendidikan Islam, Jakarta:

Ciputat Press, 2012, .75

Volume 6 No.1 Januari 2019 
Pengawasan adalah roses untuk memastikan bahwa aktifitas sebenarnya sesuai dengan yang direncanakan. Proses pengawasan dapat melibatkan beberapa elemen-elemen yaitu: 1. Menetapkan standart kinerja, 2. Mengukur kinerja, 3. Membandingkan unjuk kerja dengan standar yang telah ditetapka, 4. Mengambil tindakan korektif saat terdeteksi penyimpanan. Dengan demikian pengawasan dapat dilakukan melalui tahap-tahap yang telah ditentukan berdasarkan perencanaan yang telah disusun. Seorang manajer dapat melakukan fungsi pengawasan tersebut secara jelas.

Dari penjelasan di atas dapat disimpulkan bahwa pengawasan dapat dirumuskan sebagai proses penetuan apa yang akan dicapai, yaitu standar apa yang sedang dilakukan berupa, pelaksanaan, menilai pelaksanaan, dan bilamana memerlukan perbaikan-perbaikan sehngga pelaksanana sesuai dengan rencana yang ditetapkan.

\section{Pengelolaan gerakan koin NU Peduli di LAZISNU Cabang Nganjuk}

Kompetensi amil dalam mengelola gerakan koin NU peduli yang berjalan di LAZISNU Cabang Nganjuk menggunakan 1. Adanya petugas yang ditunjuk oleh masing-masing tingkatan NU misalnya petugas yang ditunjuk oleh ranting NU ataupun MWCNU. Petugas diutamakan kader NU yang sudah mengikuti Pelatihan Kader Penggerak NU (PKPNU). ${ }^{149}$ 2. Petugas mendapat bisyarah atau uang lelah setiap bulannya, 3. Petugas memliki buku induk untuk mencatat pemilik gerakan koin NU Peduli dan perolehannya, 4. hasil gerakan koin NU Peduli tidak boleh dipinjam ataupun dihutang. Para petugas yang sudah dibentuk setiap bulannya akan mengambil koin yang terkumpul pada titik tertentu. Sehingga dalam pendistribusian gerakan koin NU peduli setiap tiga bulan sekali agar merata kepada masyarakat miskin. Dalam menjalankan pengelolaan gerakan koin NU peduli sangatlah penting dalam kesejahteraan masyarakat miskin.

${ }^{149}$ Pelatihan Kader Penggerak NU (PKPNU) merupakan program yang digagas oleh Pengurus Besar Nahdlatul Ulama atau NU pusat untuk melatih kader NU menjadi kader yang militant dalam banyak hal termasuk pengelolaan eknomi. 
Pengelolaan gerakan koin NU peduli yang berjalan di LAZISNU Cabang Nganjuk menggunakan metode 70\% dikelola oleh ranting, 15\% dikelola oleh MWCNU, 10\% dikelola oleh LAZISNU dan 5\% dikelola oleh PCNU dengan teknis setiap bulannya ranting menggambil di titik yang sudah ditentukan sebelumnya. Banyaknya koin yang terkumpul menjadi faktor penentu utama keberhasilan gerakan ini. Adapun faktor keberhasilan dalam menjalankan pengelolaan gerakan koin NU Peduli, antara lain:

a. Adanya pembagian kerja (division of labour) dan spesialisasi. Agar pengelolaan efektif dan efisien, produsen henfaknya menggunakan metode ilmiah dan azaz-azaz manajemen. Pembagian kerja memungkinkan dicapainya tingkat dan kualitas produksi yang lebih baik, bila di isertai dengan pengolahan yang baik. Dan akan mengurangi biaya produksi sehingga tercapainya tingkat produksi yang lebih tinggi.

b. Revolusi industry. Revolusi industri merupakan suatu peristiwa penggantian tenaga manusia dengan tenaga mesin. Revolusi itu merupakan perubahan dan pembaharuan radikal dan cepat dibidang perdagangan, industri, dan teknik di Eropa. Dampanya pengusaha besar dapat meningkat perdagangannya, sedangkan pengusaha kecil dengan peralatan kerja yang masih kuno, menjadi terdesak.

c. Perkembangan alat dan teknologi yang mencakup penggunaan komputer. Sehingga pada banyak hal manajer untuk memproduksi kaleng koin dengan tekonologi canggih kedalam pengelolaannya.

d. Perkembangan ilmu dan metode kerja yang menckup metode ilmiah, hubungan antara manusia, dan model keputusan. ${ }^{150}$ Penggunaan metode ilmiah dalam mengkaji pekerjaan memungkinkan ditemukannya metode kerja terbaik dengan pendekatan sebagai berikut: a) Pengamatan (observasi) atas metode kerja yang berlaku. b) Pengamatan terhadap metode kerja melalui pengukuran dan analisis ilmiah. c) Pelatihan kerja dengan

${ }^{150}$ Data LAZISNU Cabang Nganjuk 
metode baru. d) Pemanfaatan umpan balik dalam pengelolaan atas proses kerja.

Dalam proses pengiriman berjalan dengan lancar dan baik merupakan sesuatu hal yang sangat diharapkan. Untuk mewujudkan proses pengiriman agar selalu berjalan dengan baik, maka dibutuhkan suatu manajemen atau manajemen yang bisa mengelola keseluruhan kegiatan mulai pengiriman sampai ke tangan nahdiyilin. Adapun proses dalam gerakan koin NU peduli yaitu yang harus dilakukan pertama kali dengan membuat membuat kaleng koin, selanjutnya membuat stiker untuk ditempel pada kaleng agar lebih menarik. Setelah semua selesai maka langkah terakhir adalagh pendistribusian kepada warga Nahdliyin melalui petugas.

\section{Kendala dalam Pengelolaan Gerakan NU Peduli.}

Dalam meningkatkan kesejahteraan masyarakat miskin berbagai cara yang telah dijalankan. Akan tetapi, tak semua hal dapat terselesaikan. Adapun kendala yang dihadapi oleh manajer atau pun karyawan dalam mengelola gerakan koin NU peduli. antara lain:

a. Pengiriman kaleng koin yang terlambat. Hal yang penting dalam pengelolaan gerakan koin adalah kaleng koin, karena itu untuk pegiriman kaleng koin yang tepat sangat sulit, dikarenakan sangat banyak kaleng koin yang dikerjakan dan bahannya juga terbatas.

b. Nilai upah yang minim, dalam memproduksi kaleng koin karyawan di keluhkan dengan nilai upah yang minm. Untuk gaji di peroleh tergantung berapa banyak hasil kaleng koin yang di produksi, sedangkan harga kaleng koin ditetapkan dari lembaga. ${ }^{151}$

c. SDM (Sumber Daya Manusia) yakni segala kegiatan baik jasmani maupun rohani dalam proses produksi untuk menghasilkan barang dan jasa maupun faedah suatu barang. Tenaga kerja manusia dapat diklasifikasikan tingkatannya (kualitasnya) yang terbagi atas: 1) Tenaga kerja terdidik (skilled labour), adalah tenaga kerja yang memperoleh pendidikan baik formal maupun non formal. 2) Tenaga kerja terlatih (trained labour), adalah tenaga kerja yang

${ }^{151}$ Data LAZISNU Cabang Nganjuk 
terlatih memperoleh keahlian berdasarkan latihan dan pengalman. 3) Tenaga kerja tak terdidik dan tak terlatih (unskilled and untrained labour), adalah tenaga kerja yang mengandalkan kekuatan jasmani daripada rohani.

d. Modal, dalam hal ini adalah barang atau hasil produksi yang digunakan untuk menghasilkan produk lebih lanjut. Misalkan orang membuat jala untuk mencari ikan. Dalam hal ini jala merupakan barang modal. Karena jala merupakan hasil produksi yang digunakan untuk menghasilkan produk lain (ikan). Di dalam proses produksi, modalnya dapat berupa peralatan-peralatan dan bahan-bahan:

e. Sumber daya pengusaha atau disebut juga kewirausahaan. Pengusaha berperan mengatur dan mengkombinasikan faktorfaktor produksi dalam rangka meningkatkan kegunaan barang atau jasa secara efektif dan efisien. Pengusaha berkaitan dengan manajemen. Sebagai pemicu proses produksi. Pengusaha perlu memiliki kemampuan yang dapat diandalkan. Untuk mengatur dan mengkombinaksikan faktor-faktor produksi, pengusaha harus mempunyai kemampuan merencanakan, mengorganisasikan, megarahkan, dan mengendalikan usaha.

\section{Kesimpulan}

Kompetensi amil dalam mengelola gerakan koin NU peduli yang berjalan di LAZISNU Cabang Nganjuk menggunakan 1. Adanya petugas yang tunjuk ditingkat masing-masing (ranting ataupun MWCNU), diutamakan yang sudah mengikuti PKPNU (sistem pengkaderan di NU), 2. Petugas mendapat bisyarah setiap bulannya, 3 . Petugas memliki buku induk untuk mencatat pemilik gerakan koin NU Peduli dan perolehannya, 4.hasil gerakan koin NU Peduli tidak boleh dipinjam ataupun dihutang. Para karyawannya untuk mengelola gerakan koin NU peduli dan setiap bulannya diambil setiap rumahrumah Nahdliyin. Sehingga dalam pendistribusian gerakan koin NU peduli setiap tiga bulan sekali agar merata kepada masyarakat miskin. Dalam menjalankan pengelolaan gerakan koin NU peduli sangatlah penting dalam kesejahteraan masyarakat miskin. 
Pengelolan yang berjalan di LAZISNU mengunakan metode metode $70 \%$ dikelola oleh ranting, $15 \%$ dikelola oleh MWCNU, $10 \%$ dikelola oleh LAZISNU dan 5\% dikelola oleh PCNU, yang dimana dikerjakan dengan tenaga ahli dalam bidangnya. Sedangkan kendala yang dihadapi dalam mengelola gerakan koin NU Peduli yaitu pengiriman barang yang terlambat, upah petugas yang minim, kemampuan SDM yang kurang dalam pengelolaan uang, modal minim, dan sumber daya pengusaha yang tidak ada. Saran

1. Bagi LAZISNU untuk selalu mengedepankan sikap tanggap karyawan dan perhatian dalam segala kesulitan yang di hadapi. Serta di harapakan dapat meningkatkan nilai upah karyawan dalam pembuatan kaleng koin yang dapat meringankan beban karyawan.

2. Bagi manajer di harapakan meningkatkan ilmu teknologi agar dalam mengelola gerakan koin NU Peduli lebih semaksimal mungkin. Selain itu di harapkan dapat bersaing dengan pemasar yang lain.

3. Serta diharapkan adanya support masyarakat sekitar yang saat ini belum aktif dalam hal gerakan koin NU Peduli, terutama yang belum mengikuti kegiatan ini.

\section{Daftar Pustaka}

E. Mulyasa, Manajemen Berbasis Sekolah, Cet I (Bandung: Pt. Remaja Rasindo, 2010),

Ibrahim, Metode Penelitian Kualitatif, Bandung: Alfa Beta, 2015:69

Imam Gunawan, Metode Penelitian, Jakarta: Bumi Aksara, 2014, 177

Tandikkarma Karim, Ekonomi Mikro Islam. Jakarta: PT. Raja Grafindo, 2011

Philip Kotler, Manajemen Pemasaran Jakarta, 2013

Khirunnisa', Pola Perkembangan Bank Syariah Dalam Manajemen Bisnis Islam kota Banda Aceh, vol 1, 2017, hlm 39

Khirunnisa', Pola Perkembangan Bank Syariah Dalam Manajemen Bisnis Islam kota Banda Aceh, vol 1, 2017, hlm 39

Khirunnisa', Pola Perkembangan Bank Syariah Dalam Manajemen Bisnis Islam kota Banda Aceh, vol 1, 2017, hlm 39 
Lexy J. Moleong, Metode Penelitian Kualitatif, 175-184

M. fuad, EtikaBisnis Surabaya, surabaya: Yudistira,2017

Manullang, Dasar-Dasar Manajemen, Yogyakarta: Gadjah Madha University Pres, 2012

MoleongLexy J, Metodologi Penelitian Kualitatif, Bandung: PT Remaja Rosdakarya, 2011

E. Mulyasa, Manajemen Berbasis Sekolah, Cet I (Bandung: Pt. Remaja Rasindo, 2010), 